\title{
Hudra Árpád \\ EGY NOBEL-DÍJAS A MAGYAR OKTATÁSÜGY ÉLÉN - SZENT-GYÖRGYI ALBERT AZ ABSZOLÚT PEDAGÓGUS
}

DOI: https://doi.org/10.32558/abszolut.2021.4

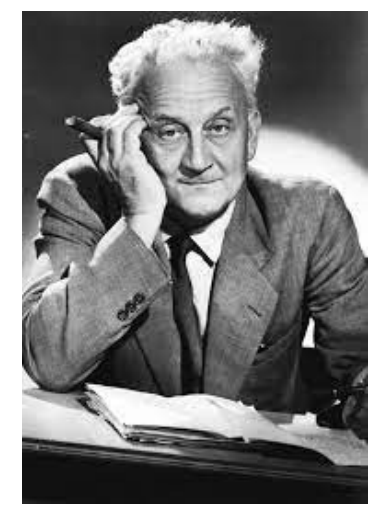

Szent-Györgyi Albert (1893-1986)

Volt, amikor Szent-Györgyi Albert az egész magyar szellemi életet, s ezen belül az oktatásügyet is irányította - idézték fel a Kiss Árpád Múhely abszolút pedagógusokkal foglalkozó sorozatának 2010. november 17-i, negyedik rendezvényén ${ }^{1}$ azt a tényt, hogy a Nobel-díjas tudós volt az 1945 áprilisában létrehozott Országos Köznevelési Tanács első elnöke (a tanács ügyvezető igazgatója akkor éppen a múhely névadója, Kiss Árpád volt.). Sokak szerint Szent-Györgyi talán legnagyobb korszaka volt ez az időszak, amikor az egész ország kultúrája és köznevelése az ő kezében futott össze. Hogy miért nem tudunk erről? Amikor 1956-ban találat érte a levéltárat a várban, elégett az Országos Köznevelési Tanács teljes iratanyaga.

Szent-Györgyi Albert alakját szemtanúként Ádám György fiziológus-orvos, az ELTE egykori rektora és a Magyar Pedagógiai Társaság elnöke idézte meg.

1 A Szent-Györgyi Albertről (1893-1986) szóló megbeszélésről készült tudósítás a Köznevelés címú hetilap 2010-es évvégi számában jelent meg H. Á. tollából. 
Bevezetőjében tisztázta, hogy nem volt tanítványa, szakmai értelemben pedig közvetlen leszármazottja a nagy magyar biokémikusnak. Először 1947 októberében látta Szent-Györgyit, amikor Kolozsvárról frissen áttelepült negyedéves budapesti orvostanhallgatóként többször is meghallgatta a híres ember izmokról szóló előadását. Magas, karcsú, őszes szőke, fiatalos és dinamikus emberként, vonzó előadóként emlékezett meg az akkor már tíz éve Nobel-kitüntetett tudósról. Azután valamikor december táján azt olvasták az újságban, hogy Szent-Györgyi külföldre ment, s már nem is jött vissza. Később ugyancsak az újságokból és szaklapokból tudták meg, hogy Szent-Györgyi távozását követően egy tengerbiológiai laboratórium igazgatója lett az Atlanti-óceán melletti Woods Hole-ban.

Ádám György akkor találkozott ismét Szent-Györgyivel, amikor már az ELTE rektoraként 1977-ben meghívta oót Budapestre, s egyúttal díszdoktorrá is avatták. A 84 éves tudós jó magyarsággal, dinamikusan megtartott előadásának témája a rákbetegség volt. Ádám szerint ugyanis Szent-Györgyit annyira hatásába kerítette második felesége 1963-ban rákbetegség miatt bekövetkezett halála, hogy attól kezdve minden idejét a rákkutatásnak szentelte. Harmadik találkozásukra 1980-ban San Franciscóban, „az amerikai TIT” (American Association for the Advancement of Science - AAAS) nagygyűlésén került sor, amelyen Ádám ismét mint aktív professzor, és a Tudományos Ismeretterjesztő Társulat elnöke találkozhatott Szent-Györgyivel és annak fiatal amerikai feleségével.

Ádám György szerint Szent-Györgyit a szakma, a biokémikusok három területen tartják számon. Az 1937-es Nobel-díj indokolása szerint mindenekelőtt a közti vagy másképpen az intermedier anyagcsere leírásáért díjazták őt. A citrát-körnek, azaz a sejtlégzésnek ezt a részletes leírását később róla és egy Krebs nevű német tudósról nevezték el Szent-GyörgyiKrebs-ciklusnak. A második terület a C-vitamin, amit ugyan nem SzentGyörgyi fedezett fel, de kiemelkedő érdeme, hogy az emberi mellékvese szövetéből izolálta, és leírta azt, valamint rájött arra is, hogy a Szegeden fellelhető piros paprikából kilószámra, azaz ipari, illetve gyógyszeripari mennyiségben lehet elóállítani. A C-vitamin végleges neve, az aszkorbinsav is tőle származik, ami a tengerészek rettegett hiánybetegségére, a skorbutra utal. A harmadik, a felfedezések szempontjából nem kevésbé jelentős kutatási terület az izommúködés, ami ugyancsak Szegedhez kötődik. SzentGyörgyi kutatótársaival, tanítványaival két izommúködési anyagot mutatott ki, a miozin és az aktin nevű fehérjéket. Szent-Györgyi-féle felfedezés, hogy ez a két egymáshoz kapcsolódó szál (a kettőt együtt nevezik aktomiozinnak), egymáson elcsúszik, amikor az izom összehúzódik. 
Ádám György szerint, jóllehet ezeket a felfedezéseket a Nobel-díjban meg sem említették, de legalább olyan jelentősek, mint az előző kettő. Amikor elkerült Amerikába, rábízta az izomkutatást magyarországi és külföldi kollégáira és elkezdett rákkal foglalkozni. Ez a negyedik témakör azonban, ahol Szent-Györgyi újból visszatért a gyökerekhez, a rosszindulatú daganatok molekuláris alapjaihoz, nem vált be, nevét e téren nem jegyzik.

Ádám György úgy látta, hogy Szent-Györgyi korának, a 20. század közepének gyermeke volt, közéletben, magánéletben, politikai „csapódásaiban” egyaránt, kiemelkedő kreativitással, tele ellentmondásokkal. Felidézte az ismert történetet is, amely szerint Szent-Györgyi még nem volt 50 éves, amikor a Kállay vezette magyar kormány titkos megbízásából elküldték őt Törökországba Magyarország háborúból való kiugrásáról tárgyalni.

Szakmai szempontból Ádám György úgy értékelte, hogy Szent-Györgyi a 30-as években a legjobb helyen, a legjobb időben volt, és ennek köszönhető, hogy akármerre nyúlt, izom, C-vitamin, citrát-kör, „,mindenütt nagyot lehetett dobni” az akkor fiatal tudománynak számító biokémiában. Utalt arra, hogy Szent-Györgyi vissza-vissza térően dolgozott főként NagyBritanniában, s angol nyelvtudása révén szabadon mozgott a nyugati szakirodalomban: „Mindenféleképpen egy nagyon tehetséges, kíváncsi, az intellektualitás magas fokán álló és az általa művelt molekuláris tudományoknak az akkori teljes tudásával rendelkező, hallatlanul eredeti gondolkodású figura volt. Mindenesetre jellemző volt rá, hogy a dolgoknak a gyökeréhez próbált meg visszamenni a kreativitása és kíváncsisága folytán” - mondta Ádám.

Pedagógusként úgy jellemezte Szent-Györgyit, hogy volt ugyan számos nyilvántartott tanítványa (Laki Kálmán, Bruckner Győző, Straub. F. Brunó, Bíró Endre és mások), de soha nem volt úgynevezett Szent-Györgyi-iskola, sem Szegeden, sem Woods Hole-ban. Nem alakultak ki klasszikus tanító-tanítványi viszonyai, noha hatott az emberekre.

A találkozón igen érdekes visszaemlékezést idézett Franyó István a Kontra Györggyel készített 1987-es Oral History-anyagból. Eszerint Szent-Györgyi Albert arról kérdezte 1945 márciusában a hozzá, az Esterházy utca 9-be (ma Puskin utca), a szovjetek által élelemmel ellátott Élettani Intézetbe sózott szalonnáért érkező Kodály Zoltánt, hogy hajlandó-e mögé állni, ha politikai szerepet vállalna. Mert ő, mármint Szent-Györgyi, nemsokára kimegy „a Sztalinhoz”, „és majd beszél a fejével, hogy akar-e valami rendes demokráciát, mert hogyha azt mondja, igen, akkor ő, Szent-Györgyi szívesen elvállalja a köztársasági elnöki tisztet, de ha nem, úgy ott hagyja őket, mint Szent Pál az oláhokat.” Az akkor orvostanhallgató 
Kontra tudomása szerint Szent-Györgyi májusban ki is repült Sztálinhoz, de talán annak még hetedik beosztottjával sem sikerült tárgyalnia.

Az előadást követő beszélgetés az emlékezések kapcsán Szent-Györgyi kreativitásának természetére kérdezett rá. Egy nonkomformista, nagyvonalú, extravagáns, rendkívüli szociális intelligenciával megáldott, tudós képe rajzolódott ki, akinek felemelkedése a tudományos életben, különösen Magyarországon, nem szokott igazán tipikus lenni. A pedagógiai tehetség, az abszolút pedagógia összefüggésében felmerült, hogy Szent-Györgyi mindenkinek a személyiségét észrevétlenül alakíthatta, anélkül, hogy arról sokat beszélt volna. Tehát attól, hogy valaki nem alapít iskolát, még nem biztos, hogy tevékenysége és személyisége hatásában nem ér fel egy iskolalapítással.

Ez a területek között közvetítő extravagáns figura már életében mítosz, és legenda volt, vetette fel Kiss Endre. A Szent-Györgyi-legendában és -mítoszban az a kivételes, hogy konstruktív mítosz volt, szemben a sok félkonstruktív vagy akár egyenesen destruktív mítosszal. Szent-Györgyi nyitott volt, szerette a társadalmat, progresszíven viszonyult a technikához, a modern életformákhoz, szélsőségesen, szinte provokatívan demokrata módjára viselkedett, kiemelkedő szociális intelligenciával rendelkezett, számos sportot űzött, a szó szoros értelmében tisztelte és támogatta az emberi kreativitás összes formáját. ${ }^{2}$

\footnotetext{
2 A beszélgetés idején még nem volt olvasható, így a tárgyalásba nem vonhattuk be WISINGER István dokumentumregényét Szent-Györgyi Albert életéről (A Nobel-dijas kém, 2016), valamint MARTON János és PAP Kornélia Szent-Györgyi 1947-ig tartó magyarországi életéről és tudományos munkásságáról írt könyvet (Kihivások, kïzdelmek, kalandok a tudományban és társadalomban, 2017), továbbá a KODOLÁNYI János Egyetem tanulmánykötetét Szent-Györgyi nevelési gondolatairól (Až emberiség jöröje a neveléstöl függ, 2019, szerkesztette MALATYINSZKY Szilárd).
} 